\title{
Transcriptional Regulation of c-jun Gene Expression by Arabinofuranosylcytosine in Human Myeloid Leukemia Cells
}

Surender M. Kharbanda, Matthew L. Sherman, and Donald W. Kufe

Laboratory of Clinical Pharmacology, Dana-Farber Cancer Institute and Harvard Medical School, Boston, Massachusetts 02115

\begin{abstract}
Previous studies have demonstrated that 1- $\beta$-D-arabinofuranosylcytosine (ara-C) induces terminal differentiation of human myeloid leukemia cells. Other studies have shown that the c-jun protooncogene is expressed during phorbol ester-induced myeloid differentiation. This work examines the effects of ara-C on c-jun gene expression in human KG-1 myeloid leukemia cells. The results demonstrate that c-jun transcripts are undetectable in uninduced KG-1 cells and that ara-C induces expression of this gene in a concentration- and time-dependent manner. Ara-C treatment was also associated with increases in c-jun transcripts in U-937, THP-1, and HL-60 myeloid leukemia cells. Furthermore, transcriptional run-on analysis has demonstrated that exposure to ara-C increases the rate of c-jun gene transcription. The results also demonstrate that while inhibition of protein synthesis superinduces c-jun mRNA levels in phorbol ester-treated KG-1 cells, cycloheximide had no effect on the induction of c-jun transcripts during ara-C treatment. Moreover, the half-life of c-jun transcripts in ara-C-treated KG-1 cells was 42 min. These findings suggest that the increase in c-jun mRNA observed during ara-C treatment is regulated by a transcriptional mechanism, and that c-jun may be involved in the induction of differentiation and regulation of gene expression by ara-C. (J. Clin. Invest. 1990. 86:1517-1523.) Key words: transcriptional activator AP-1 • differentiation • proliferation • phorbol esters $\bullet$ cycloheximide
\end{abstract}

\section{Introduction}

Avian sarcoma virus 17 (ASV 17) ${ }^{1}$ is a retrovirus that induces progressively growing fibrosarcomas in chickens and transforms cultured chicken embryo fibroblasts into elongated refractile neoplastic cells (1). The normal cellular homologue of the ASV 17 transforming gene is the c-jun protooncogene (2-4). The protein product of c-jun is structurally and functionally similar to a component of the mammalian transcriptional activator AP-1 $(5,6)$. Subsequent studies have demon-

Address reprint requests to Dr. Donald W. Kufe, Dana-Farber Cancer Institute, 44 Binney Street, Boston, MA 02115.

Received for publication 13 February 1990 and in revised form 15 June 1990.

1. Abbreviations used in this paper: ara-C, 1- $\beta$-D-arabinofuranosylcytosine; ASV, avian sarcoma virus; NBT, nitroblue tetrazolium; NSE, $\alpha$-naphthyl acetate esterase; TPA, 12-O-tetradecanoylphorbol-13-acetate.

J. Clin. Invest.

(c) The American Society for Clinical Investigation, Inc.

$0021-9738 / 90 / 11 / 1517 / 07 \quad \$ 2.00$

Volume 86, November 1990, 1517-1523 strated that c-jun is a member of a multigene family of mammalian transcription factors, which also includes jun-B, jun-D, c-fos, fos-B and fra-1 (reviewed in references 7-9). Protein members of this family interact via a common structural motif identified as a leucine zipper. Dimerization of these proteins allows the DNA binding region to recognize and bind to the heptameric DNA consensus sequence TGA $/ \mathrm{c}^{\mathrm{T}} \mathrm{TCA}$. Expression of the c-jun gene is an early response event during activation of fibroblasts and is rapidly activated by serum or phorbol esters (10-12). Furthermore, c-jun expression is induced by a number of growth factors including platelet-derived growth factor (10), fibroblast growth factor (10), epidermal growth factor (13), transforming growth factor- $\beta$ (14), tumor necrosis factor $(15,16)$, nerve growth factor (17), and IL 1 (18). Moreover, c-jun protein increases transcription of the c-jun gene by an autoregulatory mechanism (19).

$1-\beta$-D-Arabinofuranosylcytosine (ara-C) is one of the most effective agents in the treatment of human acute myelogenous leukemia (20). The mechanism(s) of action of ara-C and the basis for selectivity against leukemic cells, however, remain unclear. Ara-C is a potent inhibitor of DNA replication (21, 22). Studies with ara-C have demonstrated that inhibition of DNA synthesis is significantly related to the extent of drug incorporation into DNA (23). Moreover, there is a highly significant relationship between the formation of (ara-C) DNA and loss of clonogenic survival $(24,25)$. Ara-C also induces differentiation of mouse leukemic myeloblasts (26). Similarly, exposure of the human HL-60 (27), ML-1 (28), and U-937 (29) cell lines to ara-C results in the induction of terminal differentiation along the monocytic lineage. In this regard, induction of U-937 cells by ara-C is associated with down regulation of c-myc transcripts as well as an increase in c-fos gene expression (29).

There is presently little known about the mechanisms by which ara-C regulates gene expression. In this study, we monitored the effects of ara-C on the regulation of c-jun gene expression in human myeloid leukemia cells. We demonstrate that ara-C increases the level of c-jun transcripts in these cells and that this induction is regulated at the level of transcription.

\section{Methods}

Cell culture. KG-1 human myeloid leukemia cells (American Type Culture Collection, Rockville, MD) were grown in Iscove's modified Dulbecco media (Gibco Laboratories, Grand Island, NY) containing $10 \%$ FBS supplemented with $100 \mathrm{U} / \mathrm{ml}$ penicillin, $100 \mu \mathrm{g} / \mathrm{ml}$ streptomycin, and $2 \mathrm{mM} \mathrm{L-glutamine}$ at a density of $3-5 \times 10^{5} / \mathrm{ml}$ in $5 \% \mathrm{CO}_{2}$ humidified atmosphere at $37^{\circ} \mathrm{C}$. U-937, THP-1, and HL-60 cells were grown as previously described (30). Ara-C (Sigma Chemical Co., St. Louis, MO) was diluted in media without serum and added directly to the cell cultures. Viability was determined by trypan blue exclusion. Cytocentifuge smears of cultured cells were examined for nitroblue tetrazolium (NBT) reduction and $\alpha$-naphthyl acetate esterase (NSE) staining (31). Cell cycle analysis was performed after propidium iodide 
(Calbiochem-Behring Corp.) staining and fluorescence flow cytometry using a fluorescein-activated cell sorter equipped with the Becton Dickinson CellFIT cell cycle analysis software (Becton Dickinson \& Co., Oxnard, CA).

Preparation of RNA and Northern blot hybridization. Total cellular RNA was isolated by a modification of the guanidine-isothiocyanate technique as described previously $(30,32)$. Total cellular RNA $(20 \mu \mathrm{g})$ was subjected to electrophoresis in a $1 \%$ agarose/2.2 $\mathrm{M}$ formaldehyde gel, transferred to nitrocellulose paper, and hybridized to one of the following ${ }^{32} \mathrm{P}$-labeled DNA probes: $(a)$ the 1.8-kb Bam HI/Eco RI insert of a human c-jun DNA probe containing a 1.0-kb cDNA and 0.8-kb 3'-untranslated sequences (5) purified from a pBluescript $\mathrm{SK}(+)$ plasmid (provided by Dr. R. Tjian, University of California Berkeley); and $(b)$ the pAl plasmid containing a 2.0-kb Pst I insert of the chicken $\beta$-actin gene (33). The hybridization was carried out for $16-24 \mathrm{~h}$ at $42^{\circ} \mathrm{C}$ in $50 \%$ (vol/vol) formamide, $2 \times$ SSC (SSC: $0.15 \mathrm{M}$ sodium chloride, $0.015 \mathrm{M}$ sodium citrate), $1 \times$ Denhardt's solution, $0.1 \%$ (wt/ vol) SDS and $200 \mu \mathrm{g} / \mathrm{ml}$ salmon sperm DNA. Filters were washed and exposed to Kodak X-Omat XAR film using an intensifying screen. The autoradiograms were scanned using a laser densitometer.

Nuclear run-on assays. KG-1 cells were treated as indicated, pelleted at $500 \mathrm{~g}$ and washed twice with ice-cold PBS. The cells $\left(10^{8}\right)$ were then resuspended in $4 \mathrm{ml}$ of ice-cold lysis buffer $(10 \mathrm{mM}$ Tris $\mathrm{HCl}, \mathrm{pH}$ $7.4,10 \mathrm{mM} \mathrm{NaCl}, 3 \mathrm{mM} \mathrm{MgCl}, 0.5 \% \mathrm{NP}-40$ ), vortexed gently for $20 \mathrm{~s}$ and left on ice for $5 \mathrm{~min}$. Nuclei were then pelleted for at $500 \mathrm{~g}$ for 5 min. The supernatant was removed and the nuclei resuspended in 100 $\mu$ l glycerol buffer $(50 \mathrm{mM}$ Tris $\mathrm{HCl}, \mathrm{pH} 8.3,40 \%$ glycerol, $5 \mathrm{mM}$ $\mathrm{MgCl}_{2}, 0.1 \mathrm{mM} \mathrm{Na} \mathrm{F}_{2} \mathrm{EDTA}$ ). An equal volume of reaction buffer (10 $\mathrm{mM}$ Tris $\mathrm{HCl}, \mathrm{pH} 8.0,5 \mathrm{mM} \mathrm{MgCl}, 100 \mathrm{mM} \mathrm{KCl}, 1 \mathrm{mM}$ ATP, $1 \mathrm{mM}$ CTP, $1 \mathrm{mM} \mathrm{GTP,} 5 \mathrm{mM}$ DTT) was added to the nuclei suspension and incubated at $26^{\circ} \mathrm{C}$ for $30 \mathrm{~min}$ with $200 \mu \mathrm{Ci}\left(\alpha-{ }^{32} \mathrm{P}\right) \mathrm{UTP}(>800 \mathrm{Ci} /$ mmol; Amersham Corp., Arlington Heights, IL). Transcription was terminated by addition of $40 \mathrm{U}$ DNase $\mathrm{I}, 10 \mathrm{mM}$ Tris $\mathrm{HCl}, \mathrm{pH} 7.4,100$ $\mathrm{mM} \mathrm{NaCl}, 1 \mathrm{mM} \mathrm{Na}{ }_{2}$ EDTA, $60 \mu \mathrm{g} / \mathrm{ml}$ yeast tRNA and $150 \mathrm{U} / \mathrm{ml}$ RNasin for $15 \mathrm{~min}$ at $26^{\circ} \mathrm{C}$. Proteinase $\mathrm{K}(750 \mu \mathrm{g} / \mathrm{ml})$ and $1 \%$ (vol/vol) SDS were then added for $30 \mathrm{~min}$ at $37^{\circ} \mathrm{C}$. Nuclear RNA was isolated by phenol/chloroform extractions and then ethanol precipitated three times in $2.5 \mathrm{M}$ ammonium acetate. RNA was purified through a spin column prepared with Sephadex G50 equilibrated in and eluted with column buffer $\left(0.3 \mathrm{M} \mathrm{NaCl}, 0.1 \% \mathrm{SDS}, 1 \mathrm{mM} \mathrm{Na} \mathrm{N}_{2}\right.$ EDTA, $10 \mathrm{mM}$ Tris $\mathrm{HCl}, \mathrm{pH} 7.5$ ).

Plasmid DNAs containing various cloned inserts were digested with restriction endonucleases as follows: $(a)$ the $2.0-\mathrm{kb}$ Pst I fragment of the chicken $\beta$-actin pA1 plasmid; and $(b)$ the 1.8-kb Bam HI/Eco RI

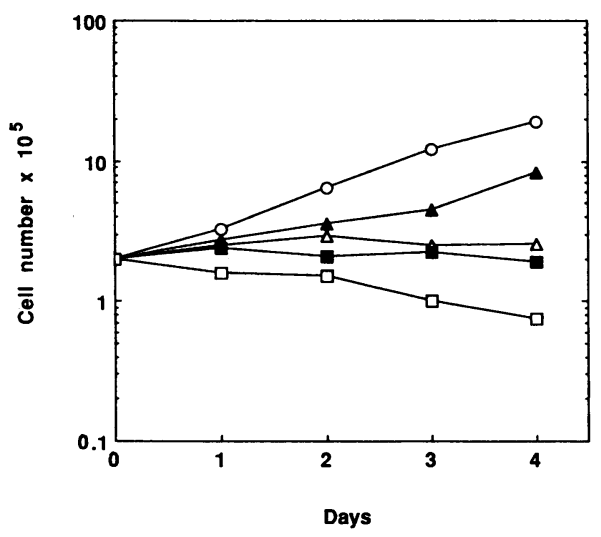

Figure 1. Effects of ara-C on KG-1 cell growth. KG-1 cells in logarithmic growth phase were seeded at $2 \times 10^{5} / \mathrm{ml}$. Ara-C was added at varying concentrations and cell number monitored at the indicated times. Viability was determined by the trypan blue exclusion. Control, o; $10^{-7} \mathrm{M}$ ara-C, $\Delta ; 10^{-6} \mathrm{M}$ ara-C, $\Delta ; 10^{-5} \mathrm{M}$ ara-C, $\mathrm{n} ;$ and $10^{-4}$ $\mathrm{M}$ ara-C, $\square$.
Table I. Effect of Ara-C on NBT and NSE Staining of KG-1 Cells

\begin{tabular}{|c|c|c|}
\hline $\begin{array}{l}\text { Time of } \\
\text { exposure }\end{array}$ & NBT positive & NSE positive \\
\hline$h$ & & \\
\hline 0 & $4.4 \pm 0.2$ & $7.5 \pm 1.1$ \\
\hline 12 & $7.4 \pm 1.0$ & $13.5 \pm 1.6$ \\
\hline 24 & $7.0 \pm 1.9$ & $24.1 \pm 3.8$ \\
\hline 48 & $9.5 \pm 2.3$ & $39.5 \pm 5.7$ \\
\hline
\end{tabular}

KG-1 cells were treated with $5 \times 10^{-6} \mathrm{M}$ ara-C for the indicated times. The percentage of NSE and NBT positive cells was determined by counting 200 cells in duplicate. Results are expressed as mean $\pm S D$ of two experiments each performed in duplicate.

fragment of the human c-jun cDNA from the pBluescript SK(+) plasmid. The digested DNA was denatured by heating to $65^{\circ} \mathrm{C}$ for $15 \mathrm{~min}$, separated in a $1 \%$ agarose gel and transferred to nitrocellulose filters by the method of Southern. The filters were prehybridized in $5 \times$ Denhardt's solution, $40 \%$ formamide, $4 \times$ SSC, $5 \mathrm{mM} \mathrm{Na} \mathrm{N}_{2}$ EDTA, $0.4 \%$ SDS, and $100 \mu \mathrm{g} / \mathrm{ml}$ yeast tRNA for $2 \mathrm{~h}$. Hybridizations was performed with $10^{7} \mathrm{cpm}$ of ${ }^{32} \mathrm{P}$-labeled RNA per ml hybridization buffer for $72 \mathrm{~h}$ at $42^{\circ} \mathrm{C}$. The filters were then washed in $2 \times$ SSC and $0.1 \%$ SDS at $37^{\circ} \mathrm{C}$ for $30 \mathrm{~min}, 10 \mu \mathrm{g} / \mathrm{ml} \mathrm{RNase} \mathrm{A}$ in $2 \times \mathrm{SSC}$ at $37^{\circ} \mathrm{C}$ for $20 \mathrm{~min}$ and $0.1 \times$ SSC and $0.1 \%$ SDS at $42^{\circ} \mathrm{C}$ for $30 \mathrm{~min}$.

\section{Results}

KG-1 cells were treated with various concentrations of ara-C to determine the effects of this agent on cell growth. Although $10^{-7} \mathrm{M}$ ara-C had partial growth inhibitory effects, proliferation was completely inhibited in the presence of $10^{-6}$ and $10^{-5}$ $\mathrm{M}$ drug (Fig. 1). In contrast, exposure to $10^{-4} \mathrm{M}$ ara-C for $72 \mathrm{~h}$ was associated with cell lethality (Fig. 1). The effects of ara-C on phenotypic differentiation were also determined by moni-

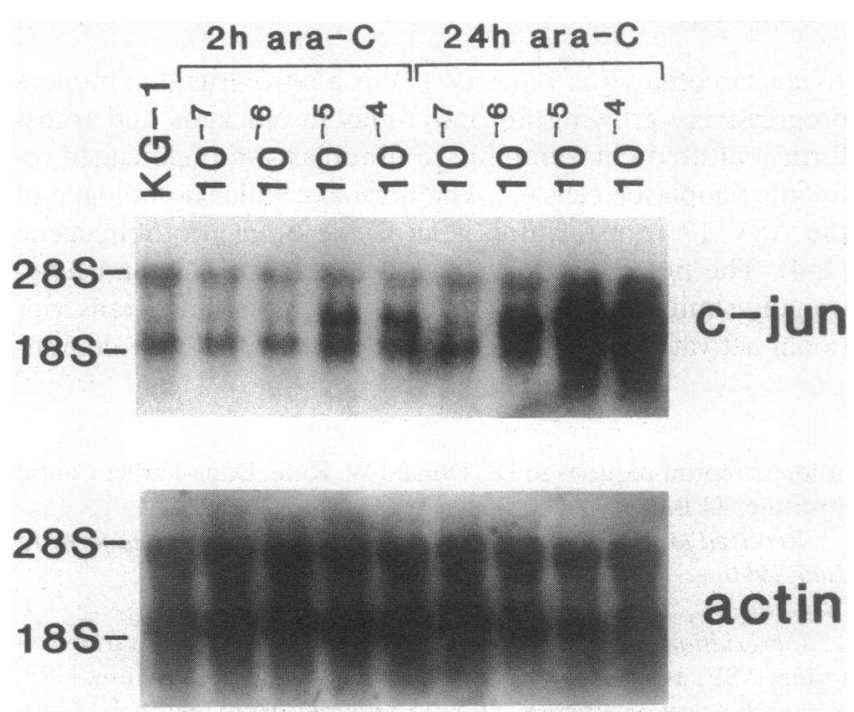

Figure 2. Effects of ara-C on c-jun and actin RNA levels in KG-1 cells. Northern blot analysis of RNA levels was performed in KG-1 cells after treatment with varying concentrations of ara-C for 2 and $24 \mathrm{~h}$. Total cellular RNA ( $20 \mu \mathrm{g} /$ lane) was hybridized to a ${ }^{32} \mathrm{P}$-labeled c-jun or $\beta$-actin DNA probe. The KG-1 lane represents RNA from untreated cells. 
toring changes in histochemical staining. While $7.5 \%$ of untreated KG-1 cells were NSE positive, $39.5 \%$ of these cells stained positively for NSE after $48 \mathrm{~h}$ of exposure to ara-C (Table I). In contrast, ara-C treatment was associated with little, if any, change in the percentage of cells that reduced NBT (Table I). These results suggest that ara-C induces KG-1 cells along the monocytic lineage.

We next studied the effects of various concentrations of ara-C on c-jun gene expression in KG-1 cells. Northern blot analysis of KG-1 cellular RNA collected at 2 and $24 \mathrm{~h}$ of drug exposure is shown in Fig. 2. c-jun transcripts were undetectable in untreated KG-1 cells, and exposure to $10^{-7}$ or $10^{-6} \mathrm{M}$ ara-C for $2 \mathrm{~h}$ had little effect on expression of this gene. In contrast, treatment with $10^{-5} \mathrm{M}$ and $10^{-4} \mathrm{M}$ ara-C for $2 \mathrm{~h}$ resulted in induction of 2.7-kb c-jun transcripts. Lower concentrations of ara-C $\left(10^{-6} \mathrm{M}\right)$ also induced c-jun expression after $24 \mathrm{~h}$ of treatment (Fig. 2). Furthermore, the changes in c-jun mRNA levels were associated with little if any effect of ara- $\mathrm{C}$ on actin gene expression. These findings suggested that ara- $\mathrm{C}$ treatment specifically increases $c-j u n$ expression in a concentration- and time-dependent manner.

The effects of ara-C on the kinetics of c-jun expression were next studied using a cytostatic concentration of drug. c-jun transcripts reached maximal levels by $6-8 \mathrm{~h}$ of exposure to 5 $\times 10^{-6} \mathrm{M}$ ara-C and declined by $10 \mathrm{~h}$ (Fig. $3 \mathrm{~A}$ ). Furthermore, c-jun mRNA levels remained elevated at $24 \mathrm{~h}$ of ara-C exposure before returning to that in control cells by $72 \mathrm{~h}$ (Fig. $3 \mathrm{~B}$ ). These findings were also associated with the absence of a detectable effect on actin gene expression. Similar studies were performed using serum-starved cells. KG-1 cells were grown in $1 \%$ serum for $18 \mathrm{~h}$ and then exposed to ara-C. After $6 \mathrm{~h}$, a significant increase in c-jun mRNA levels was observed in the absence of serum (Fig. $3 \mathrm{C}$ ).

To determine the effects of cell cycle on induction of c-jun by ara-C, KG-1 cells were treated with $5 \times 10^{-6} \mathrm{M}$ ara-C for varying times and analyzed by fluorescence flow cytometry. While $53.4 \%$ of untreated $\mathrm{KG}-1$ cells were in $\mathrm{G}_{1}$ phase, $75.2 \%$ of these cells were in $\mathrm{G}_{1}$ after $24 \mathrm{~h}$ of ara-C exposure (Table II).
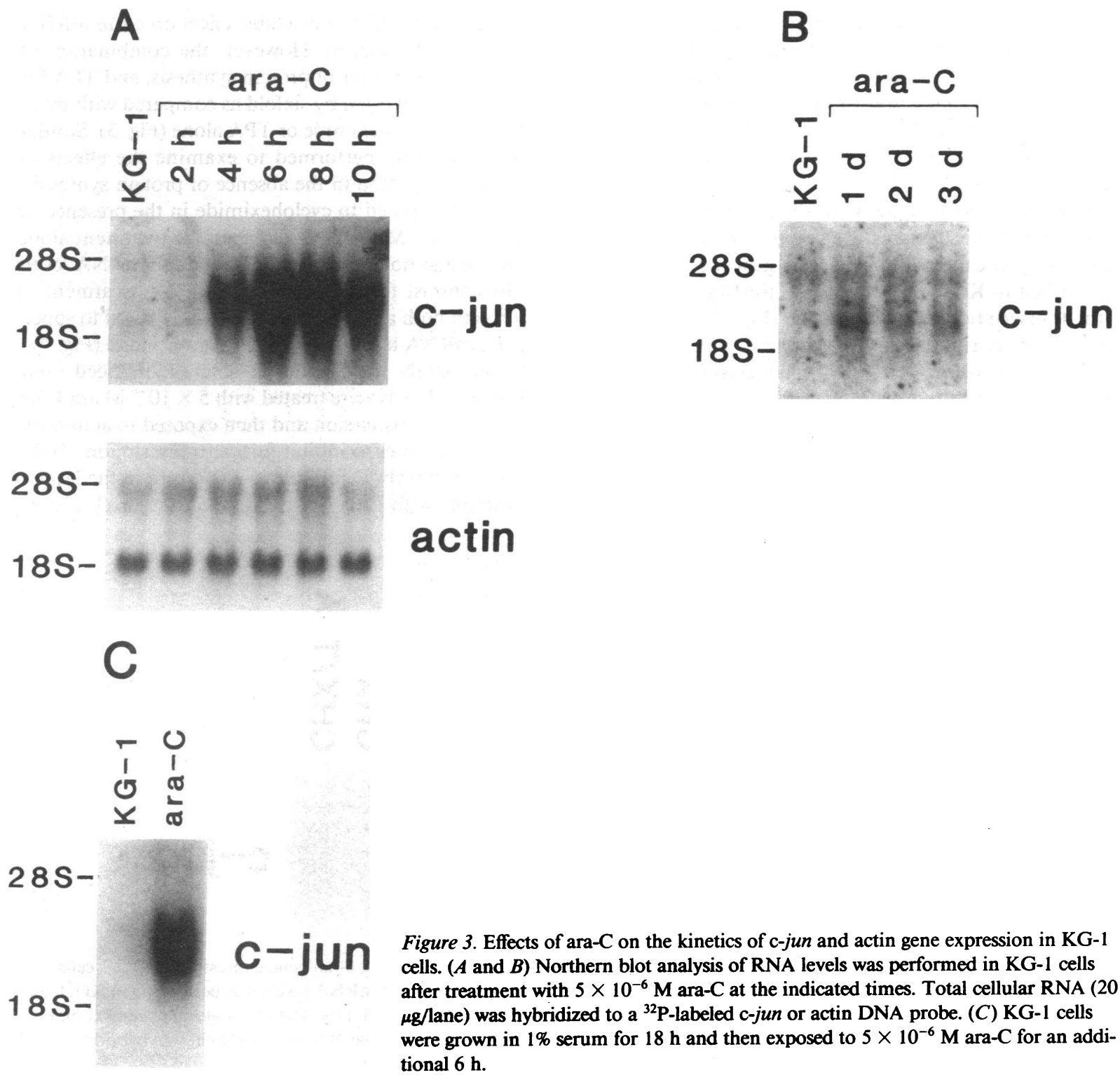

Figure 3. Effects of ara-C on the kinetics of c-jun and actin gene expression in KG-1 cells. $(A$ and $B$ ) Northern blot analysis of RNA levels was performed in KG-1 cells after treatment with $5 \times 10^{-6} \mathrm{M}$ ara-C at the indicated times. Total cellular RNA (20 $\mu \mathrm{g} /$ /ane) was hybridized to a ${ }^{32} \mathrm{P}$-labeled c-jun or actin DNA probe. $(C) \mathrm{KG}-1$ cells were grown in $1 \%$ serum for $18 \mathrm{~h}$ and then exposed to $5 \times 10^{-6} \mathrm{M}$ ara-C for an additional $6 \mathrm{~h}$. 
Table II. Cell Cycle Analysis of Ara-C-treated KG-1 Cells

\begin{tabular}{cccr}
\hline $\begin{array}{c}\text { Time of } \\
\text { exposure }\end{array}$ & $\mathrm{G}_{1}$ & $\mathrm{~S}$ & $\mathrm{G}_{2} / \mathrm{M}$ \\
\hline$h$ & & $\%$ & \\
0 & $53.4 \pm 2.4$ & $36.0 \pm 0.8$ & $10.5 \pm 1.6$ \\
6 & $72.7 \pm 1.1$ & $21.8 \pm 0.7$ & $5.5 \pm 0.3$ \\
24 & $75.2 \pm 8.3$ & $20.2 \pm 6.8$ & $4.7 \pm 1.5$
\end{tabular}

KG-1 cells were exposed to $5 \times 10^{-6} \mathrm{M}$ ara-C for the indicated times. The percentage of cells in $G_{1}, S$, and $G_{2} / M$ phase was determined by fluorescence flow cytometry.

In contrast, the percentage of cells in $S$ and $G_{2} / M$ phase decreased from .36 and $10.5 \%$ to 20.2 and $4.7 \%$, respectively (Table II). These results confirm that ara-C inhibits S-phase DNA synthesis and accumulates cells in the $G_{1} / S$ interphase.

Previous studies have demonstrated that exposure of human HL-60 and U-937 cells to ara-C results in the induction of terminal differentiation along the monocytic lineage $(27,29)$. Thus, it was also of interest to determine the effects of ara-C on c-jun expression in other myeloid cell lines. Ara-C treatment was associated with increases in c-jun transcripts in U-937, THP-1, and HL-60 cells, although the relative levels of induction varied among the cell lines (Fig. 4). These results indicate that ara-C induces c-jun expression in several human myeloid leukemia cell lines.

Run-on transcription assays were performed to determine whether transcriptional mechanisms are responsible for the effects of ara-C on c-jun expression. The actin gene was constitutively transcribed in KG-1 cells and ara-C treatment had no effect on the transcription rate of this gene (Fig. 5). A low level of c-jun gene transcription was detectable in untreated KG-1 cells. However, exposure to ara-C for $6 \mathrm{~h}$ was associated with a sixfold increase in c-jun gene transcription (Fig. 5). Taken together, these results suggested that the induction of c-jun expression by ara-C is regulated by a transcriptional mechanism.

We and others have recently shown that treatment of human myeloid leukemia cells with phorbol esters, such as 12-O-tetradecanoylphorbol-13-acetate (TPA), is associated with induction of c-jun transcripts $(30,34)$. Consequently, it

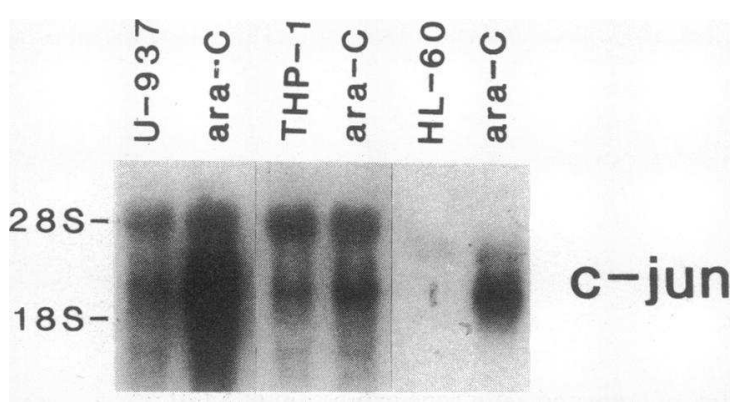

Figure 4. Effect of ara-C on c-jun RNA levels in other myeloid leukemia cell lines. Northern blot analysis of mRNA levels were performed in U-937, THP-1 and HL-60 cells after treatment with 5 $\times 10^{-6} \mathrm{M}$ ara-C for $6 \mathrm{~h}$. Total cellular RNA (20 $\left.\mu \mathrm{g} / \mathrm{lane}\right)$ was hybridized to a ${ }^{32} \mathrm{P}$-labeled c-jun probe.
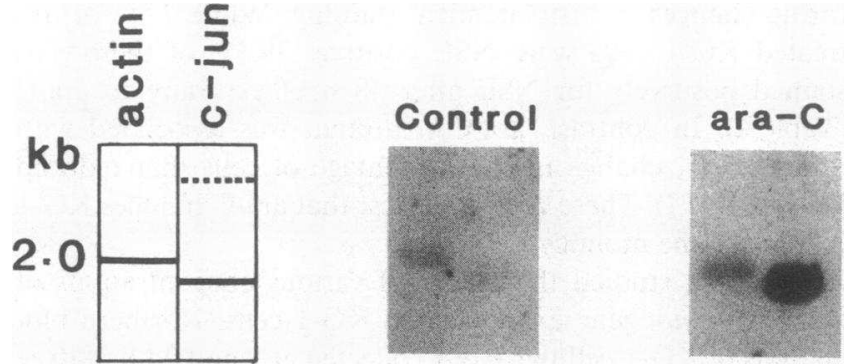

Figure 5. Effects of ara-C on rates of c-jun gene transcription in KG-1 cells. Digested actin and c-jun plasmid DNAs were run on a $1 \%$ agarose gel, transferred to nitrocellulose paper by Southern blotting, and hybridized to equal amounts of ${ }^{32} \mathrm{P}$-labeled nuclear RNA $\left(5-6 \times 10^{6} \mathrm{cpm} / \mathrm{ml}\right)$ isolated from control and ara-C-treated KG-1 cells. In the schematic on the left, the solid lines indicate the relative positions of the cDNA inserts while the dashed line indicates the position of the plasmid vector (negative control).

was of interest to determine if the effects of TPA on c-jun mRNA could also be demonstrated in KG-1 cells. In contrast to HL-60 cells, TPA had no detectable effect on c-jun mRNA levels in KG-1 cells (Fig. 6). However, the combination of cycloheximide, an inhibitor of protein synthesis, and TPA for $4 \mathrm{~h}$ increased levels of c-jun by sixfold as compared with treatment with either cycloheximide or TPA alone (Fig. 5). Similar studies were therefore performed to examine the effects of ara-C on c-jun expression in the absence of protein synthesis. KG-1 cells were exposed to cycloheximide in the presence or absence of $5 \times 10^{-6} \mathrm{M}$ ara-C. Cycloheximide treatment alone for 1,3 , or $6 \mathrm{~h}$ had no detectable effect on c-jun mRNA levels (Fig. 7). In contrast to the findings with TPA, treatment of KG-1 cells with both ara-C and cycloheximide failed to superinduce c-jun mRNA levels compared to ara-C alone (Fig. 7).

To further study the regulation of ara-C-induced c-jun RNA levels, KG- 1 cells were treated with $5 \times 10^{-6} \mathrm{M}$ ara-C for $6 \mathrm{~h}$ to induce c-jun expression and then exposed to actinomycin $\mathrm{D}$ for varying times to inhibit further transcription. Treatment with actinomycin $D$ resulted in a decrease in the level of c-jun transcripts with little if any effect on the level of actin

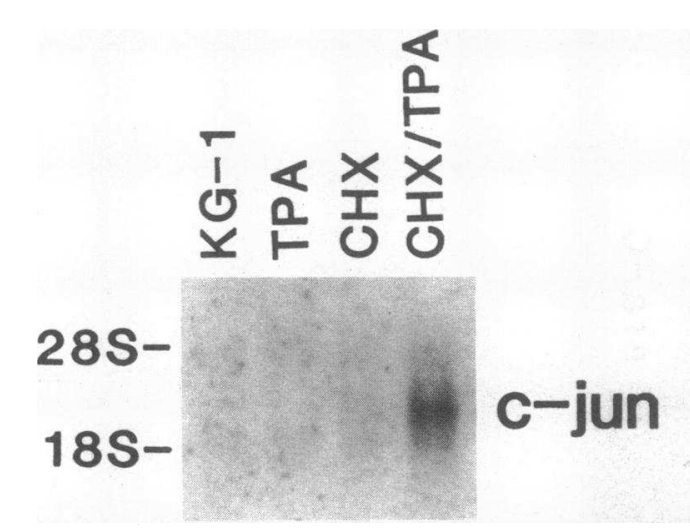

Figure 6. Effects of TPA on c-jun gene expression in KG-1 cells. Northern blot analysis of mRNA levels was performed in KG-1 cells after treatment with $32 \mathrm{nM}$ TPA and/or $10 \mu \mathrm{g} / \mathrm{ml}$ cycloheximide (CHX) for $4 \mathrm{~h}$. Total cellular RNA ( $20 \mu \mathrm{g} / \mathrm{lane})$ was hybridized to a ${ }^{32}$ P-labeled c-jun DNA probe. 


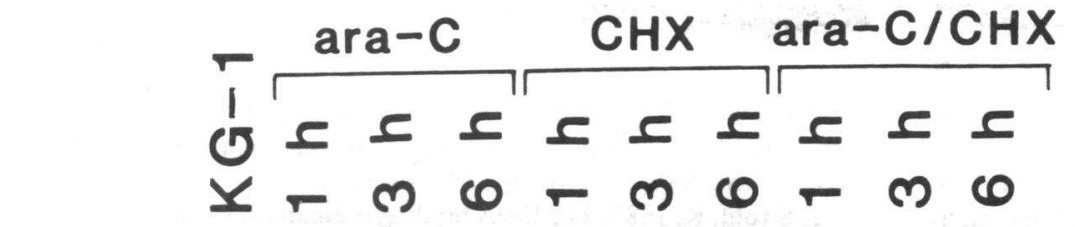

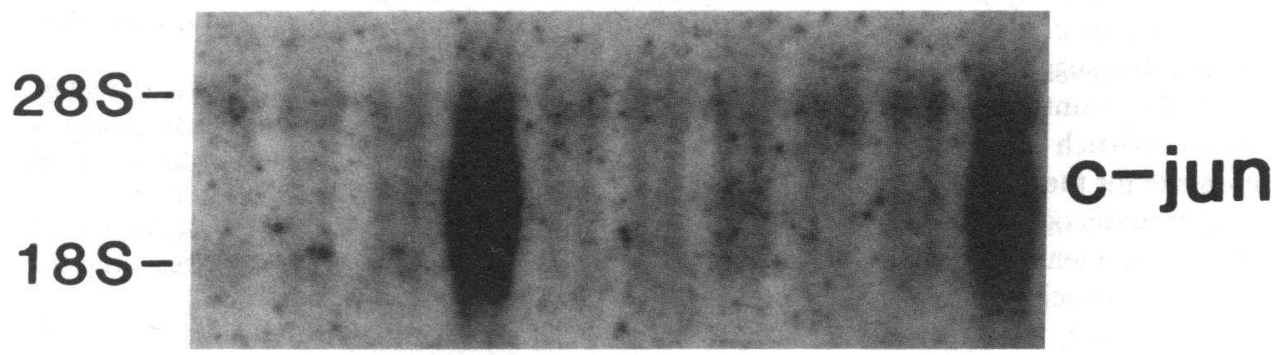

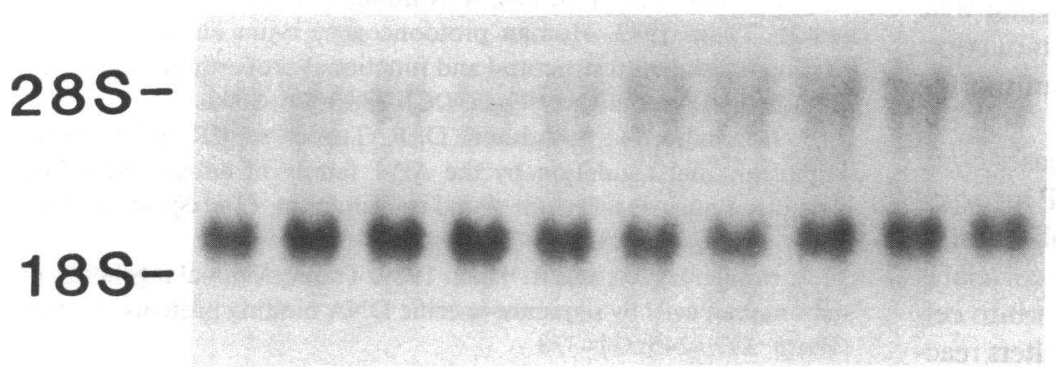

Figure 7. Effect of ara-C and cycloheximide on c-jun and actin gene expression. Northern blot analysis of mRNA levels was performed in KG-1 cells after treatment with 5 $\times 10^{-6} \mathrm{M}$ ara-C and/or $10 \mu \mathrm{g} / \mathrm{ml}$ cycloheximide $(\mathrm{CHX})$ at the indicated times. Total cellular RNA ( 20 $\mu \mathrm{g} /$ lane) was hybridized to ${ }^{32} \mathrm{P}$-labeled c-jun or actin DNA probe.
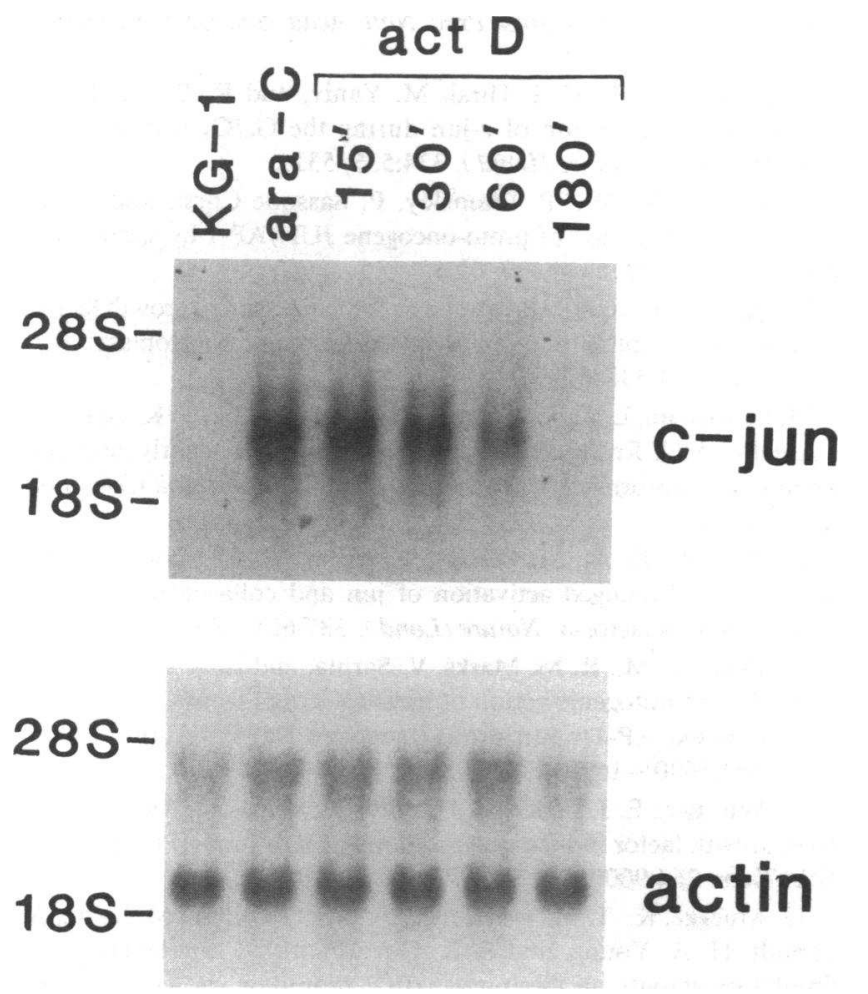

Figure 8. Effect of ara-C and actinomycin D on c-jun and actin gene expression. Northern blot analysis of RNA levels was performed in KG-1 cells after treatment with $5 \times 10^{-6} \mathrm{M}$ ara- $\mathrm{C}$ alone or in combination with $5 \mu \mathrm{g} / \mathrm{ml}$ actinomycin $\mathrm{D}$ (act $\mathrm{D}$ ) at the indicated times. Total cellular RNA ( $20 \mu \mathrm{g} /$ lane) was hybridized to ${ }^{32} \mathrm{P}$-labeled c-jun or actin DNA probe.
mRNA (Fig. 8). The half-life of c-jun mRNA in KG-1 cells as determined by densitometeric scanning was $42 \mathrm{~min}$. Moreover, cycloheximide had little if any effect on the half-life of c-jun transcripts in these cells (data not shown). The stability of c-jun mRNA was also determined in both untreated and ara-C-treated U-937 cells. Untreated U-937 exposed to actinomycin $\mathrm{D}$ for varying times resulted in a decrease in the level of constitutively expressed c-jun transcripts. The half-life of c-jun mRNA was determined by densitometric scanning was 30 min. U-937 cells were also treated with $5 \times 10^{-6} \mathrm{M}$ ara-C for $6 \mathrm{~h}$ to induce c-jun expression and then exposed to actinomycin $\mathrm{D}$ to inhibit further transcription. Under these conditions, the half-life of c-jun mRNA was determined to be 30 min. Taken together, these results suggest that ara-C has little if any effect on the stability of c-jun mRNA.

\section{Discussion}

In the present study, we have demonstrated that ara- $C$ increases c-jun RNA levels in KG- 1 cells in a concentration- and time-dependent manner. Analysis of relative rates of gene transcription showed that ara-C treatment of KG-1 cells is associated with significant increases in c-jun gene transcription. These results indicate that the induction of c-jun by ara-C is mediated, at least in part, by a transcriptional mechanism. Regulation of c-jun expression by transcriptional mechanisms has also been described for serum, phorbol esters, and certain growth factors. A rapid increase in c-jun transcription occurs during the $G_{0} / G_{1}$ transition in mouse fibroblasts (11). Because ara-C inhibits $S$ phase DNA synthesis and accumulates cells at the $G_{1} / S$ interphase, the present findings might be explained 
by cell cycle-related events. However, similar exposures to cytostatic concentrations of aphidicolin, an inhibitor of DNA polymerase $\alpha$ (35), had no detectable effect on c-jun expression (data not shown).

The induction of c-jun RNA after treatment with TPA or growth factors in certain cell lines is also regulated by posttranscriptional mechanisms. The stabilization of c-jun transcripts following protein synthesis inhibition has suggested the presence of a labile ribonuclease. Indeed, the $3^{\prime}$-untranslated region of the c-jun transcript contains an AU-rich sequence that has been implicated as a recognition site for the degradation of mRNAs coding for a variety of protooncogenes and growth factors $(36,37)$. We have found that treatment of KG-1 cells with both TPA and cycloheximide is also associated with superinduction of c-jun mRNA levels. In contrast, treatment of KG-1 cells with ara-C and cycloheximide showed no increase in levels of c-jun mRNA compared with that obtained during treatment with ara- $\mathrm{C}$ alone. These results suggest that induction of c-jun expression by ara-C differs from induction by TPA and that there are at least two separate mechanisms for regulating c-jun mRNA levels in KG-1 cells.

The molecular mechanism by which ara-C increases c-jun transcripts is unclear. The active metabolite, ara-CTP incorporates into DNA and is a potent inhibitor of DNA replication in eukaryotic cells (23-25). Ara-C-induced cytotoxicity correlates significantly with the amount of ara-C incorporation into cellular DNA $(24,25)$. The incorporated ara-C residue alters reactivity of the $3^{\prime}$ terminus, slows chain elongation and results in DNA fragmentation (23). Moreover, the relative chain-terminating effects of ara- $\mathrm{C}$ are dependent on the concentration of drug and sequence of the elongating DNA strand $(38,39)$. Although ara-C might incorporate into the promoter region of the c-jun gene and thereby possibly alter rates of transcription, this mechanism would appear to be an unlikely explanation for the marked induction of this gene. Another possibility might include ara-C-induced decreases in the expression of a trans-acting factor involved in the negative regulation of c-jun transcription. The cis-acting elements in the c-jun promoter have been defined and thus additional studies are now needed to define more precisely the mechanism whereby ara-C induces transcription of this gene.

Finally, the increase in c-jun gene expression by ara-C may in turn induce other genes with a c-jun/AP-1 binding site. Treatment of myeloid leukemia cells with ara-C is associated with decreases in c-myc mRNA levels, as well as an increase in c-fos gene expression (29). In this regard, c-jun/AP-1-like sequences in the $5^{\prime}$ regulatory region of $c-m y c$ have been implicated in the down regulation of this gene $(40,41)$. Thus, the transient increase in c-jun expression by ara-C may initiate specific transcriptional events necessary for the regulation of certain other genes associated with ara-C-induced myeloid differentiation.

\section{Acknowledgments}

This investigation was supported in part by U. S. Public Health Service grant CA-29431 awarded by the National Cancer Institute, Department of Health and Human Services; by a Clinical Investigator Award K08 CA01092 (M. L. Sherman); and by a Burroughs-Wellcome Clinical Pharmacology Scholar Award (D. W. Kufe).

\section{References}

1. Cavalieri, F., T. Ruscio, R. Tinoco, S. Benedict, C. Davis, and P. K. Vogt. 1985. Isolation of three new avian sarcoma viruses: ASV 9, ASV 17, and ASV 25. Virology. 143: 680-683.

2. Struhl, K. 1987. The DNA binding domains of the jun oncoprotein and the yeast GCN4 transcriptional activator protein are functionally homologous. Cell. 50:841-846.

3. Vogt, P. K., T. J. Bos, and R. F. Doolittle. 1987. Homology between the DNA binding domain of the GCN4 regulatory protein of yeast and the carboxyl-terminal region of a protein coded for by the oncogene jun. Proc. Natl. Acad. Sci. USA. 84:3316-3319.

4. Maki, Y., T. J. Bos, C. Davis, M. Starbuck, and P. K. Vogt. 1987. Avian sarcoma virus 17 carries the jun oncogene. Proc. Natl. Acad. Sci. USA. 84:2848-2852.

5. Angel, P., E. A. Allegretto, S. T. Okino, K. Hatton, W. J. Boyle, T. Hunter, and M. Karin. 1988. Oncogene jun encodes a sequence specific transactivator similar to AP-1. Nature (Lond.). 332:166-171.

6. Bohmann, D., T. J. Bos, A. Admon, T. Nishimura, P. K. Vogt, and $R$. Tjian. 1987. Human protooncogene c-jun encodes a DNA binding protein with structural and functional properties of transcription factor AP-1. Science (Wash. DC). 238:1386-1392.

7. Bohmann, D., A. Admon, D. R. Turner, and R. Tjian. 1988. Transcriptional regulation by the AP-1 family of enhancer-binding proteins: a nuclear target for signal transduction. Cold Spring Harbor Symp. Quant. Biol. 53:695-700.

8. Mitchell, P. J., and R. Tijan. 1989. Transcriptional regulation in mammalian cells by sequence-specific DNA binding proteins. Science (Wash. DC). 245:371-378.

9. Johnson, P. F., and S. L. McKnight. 1989. Eukaryotic transcriptional regulatory proteins. Annu. Rev. Biochem. 58:799-839.

10. Ryder, K., and D. Nathans. 1988. Induction of protooncogene c-jun by serum growth factors. Proc. Natl. Acad. Sci. USA. 85:84648467.

11. Ryseck, R. P., H. I. Hirai, M. Yaniv, and R. Bravo. 1988. Transcriptional activation of c-jun during the $G_{0} / G_{1}$ transition in mouse fibroblasts. Nature (Lond.). 334:535-537.

12. Lamph, W. W., P. Wamsley, P. Sassone-Corsi, and I. M. Verma. 1988. Induction of proto-oncogene JUN/AP-1 by serum and TPA. Nature (Lond.). 334:629-631.

13. Quantin, B., and R. Breathnach. 1988. Epidermal growth factor stimulates transcription of c-jun protooncogene in rat fibroblasts. $\mathrm{Na}$ ture (Lond.). 334:538-539.

14. Pertovaara, L., L. Sistonen, T. J. Bos, P. K. Vogt, J. K. Oja, and K. Alitalo. 1989. Enhanced jun gene expression is an early genomic response to transforming growth factor $\beta$ stimulation. Mol. Cell. Biol. 9:1255-1262.

15. Brenner, D. A., M. O'Hara, P. Angel, M. Chojikier, and M. Karin. 1989. Prolonged activation of jun and collagenase genes by tumour necrosis factor- $\alpha$. Nature (Lond.). 337:661-663.

16. Dixit, V. M., R. M. Marks, V. Sarma, and E. V. Prochownik. 1989. The antimitogenic action of tumor necrosis factor is associated with increased AP-1/c-jun proto-oncogene transcription. J. Biol. Chem. 264:16905-16909.

17. Wu, B-y., E. J. Fodor, R. H. Edwards, and W. J. Rutter. 1989. Nerve growth factor induces the protooncogene c-jun in PC12 cells. $J$. Biol. Chem. 264:9000-9003.

18. Muegge, K., T. M. Williams, J. A. Kant, R. Chui, M. Karin, A. Schmidt, H. A. Young, and S. K. Durrum. 1989. Interleukin 1 costimulatory activity on the interleukin 2 promotor via AP-1. Science (Wash. DC). 246:249-251.

19. Angel, P., K. Hattori, T. Smeal, and M. Karin. 1988. The jun proto-oncogene is positively autoregulated by its product, Jun/AP-1. Cell. 55:875-885.

20. Frei, E., J. N. Bickers, J. S. Hewlett, M. Lane, W. V. Leary, and 
R. W. Tally. 1969. Dose schedule and antitumor studies of arabinosyl cytosine (NSC 63878). Cancer Res. 29:1325-1332.

21. Furth, J., and S. Cohen. 1968. Inhibition of mammalian DNA polymerase by the 5 -triphosphate of $9-\beta$-D-arabinofuranosyladenine. Cancer Res. 28:2061-2067.

22. Graham, F., and G. Whitmore. 1970. The effect of 1- $\beta$-D-arabinofuranosylcytosine on growth, viability, DNA synthesis of mouse L-cells. Cancer Res. 30:2627-2635.

23. Major, P. P., E. M. Egan, D. Herrick, and D. W. Kufe. 1982. The effect of ara-C incorporation on DNA synthesis in cells. Biochem. Pharmacol. 31:2937-2941.

24. Major, P., E. M. Egan, G. Beardsley, M. Minden, and D. W. Kufe. 1981. Lethality of human myeloblasts correlates with the incorporation of ara-C into DNA. Proc. Natl. Acad. Sci. USA. 78:32353239.

25. Kufe, D. W., P. P. Major, and P. Beardsley. 1980. Incorporation of ara-C into L1210 DNA as a correlate of cytotoxicity. J. Biol. Chem. 225:8997-9000.

26. Lotem, J., and L. Sachs. 1974. Different blocks in the differentiation of myeloid leukemic cells. Proc. Natl. Acad. Sci. USA. 71:3507-3511.

27. Griffin, J., D. Munroe, P. Major, and D. Kufe. 1982. Induction of differentiation of human myeloid leukemic cells by inhibitors of DNA synthesis. Exp. Hematol. 10:774-781.

28. Takeda, K., J. Minowada, and A. Bloch. 1981. Kinetics of appearance of differentiation-associated characteristics in ML-1, a line of human myeloblastic leukemia cells, after treatment with 12-O-tetradecanoyl-phorbol-13-acetate, dimethyl sulfoxide, or 1- $\beta$-D-arabinofuranosylcytosine. Cancer Res. 42:5152-5158.

29. Mitchell, T., E. Sariban, and D. Kufe. 1986. Effects of 1- $\beta$-Darabinofuranosylcytosine on proto-oncogene expression in human U-937 cells. Mol. Pharmacol. 30:398-402.

30. Sherman, M. L., R. M. Stone, R. Datta, S. H. Bernstein, and D. W. Kufe. 1990. Transcriptional and post-transcriptional regulation of c-jun expression during monocytic differentiation of human myeloid leukemia cells. J. Biol. Chem. 265:3320-3323.
31. Yam, L., C. Li, and W. Crosby. 1971. Cytochemical identification of monocytes and granulocytes. Am. J. Clin. Pathol. 55:283-290.

32. Chirgwin, J., H. Przybla, R. MacDonald, and W. Rutter. 1979. Isolation of biologically active ribonucleic acid from sources enriched in ribonuclease. Biochemistry. 18:5294-5299.

33. Cleveland, D. W., M. A. Lopata, R. J. MacDonald, N. J. Cowan, W. J. Rutter, and M. W. Kirschner. 1980. Number and evolutionary conservation of $\alpha$ - and $\beta$-tubulin and cytoplasmic $\beta$ - and $\gamma$ actin genes using specific cloned cDNA probes. Cell. 20:95-105.

34. Bertani, A., N. Polentarutti, A. Sica, A. Rambaldi, A. Mantovani, and F. Colotta. 1989. Expression of c-jun protooncogene in human myelomonocytic cells. Blood. 74:1811-1816.

35. Huberman, J. 1981. New views on the biochemistry of eukaryotic DNA replication by aphidicolin, an unusual inhibitor of DNA polymerase alpha. Cell. 23:647-648.

36. Shaw, G., and R. Kamen. 1986. A conserved AU sequence from the $3^{\prime}$ untranslated region of GM-CSF mRNA mediates selective mRNA degradation. Cell. 46:659-667.

37. Caput, D., B. Beutler, K. Hertog, R. Thayer, S. Brown-Shimmer, and A. Cerami. 1986. Identification of a common nucleotide sequence in the $3^{\prime}$ untranslated region of mRNA molecules specifying inflammatory mediators. Proc. Natl. Acad. Sci. USA. 83:1670-1674.

38. Townsend, A., and Y.-C. Cheng. 1987. Sequence specific effects of ara-5-aza-CTP and ara-CTP on DNA synthesis by purified human DNA polymerases in vitro: visualization of chain elongation on a defined template. Mol. Pharmacol. 32:330-339.

39. Ohno, Y., D. Spriggs, A. Matsukage, T. Ohno, and D. Kufe. 1988. Effects of $1-\beta$-D-arabinofuranosylcyosine incorporation on elongation of specific DNA sequences by DNA polymerase $\beta$. Cancer Res. 48:1494-1498.

40. Takimoto, M., J. P. Quinn, A. R. Farina, L. M. Staudt, and D. Levens. 1989. fos/jun and octamer-binding protein interact with a common site in a negative element of the human c-myc gene. J. Biol. Chem. 264:8992-8999.

41. Hay, N., M. Takimoto, and J. M. Bishop. 1989. A FOS protein is present in a complex that binds a negative regulator of MYC. Genes \& Dev. 3:293-303. 